\title{
Origin of the Bessarabian limestones with Nubecularia novorossica of Northeastern Bulgaria
}

\author{
Elena Koleva-Rekalova ${ }^{1}$, Stefka Darakchieva \\ ${ }^{1}$ Geological Institute, Bulgarian Academy of Sciences, Acad. G. Bonchev str., Bl. 24, 1113 Sofia, Bulgaria; \\ E-mail: e_koleva@geology.bas.bg \\ ${ }^{2}$ Sofia University "St. Kliment Ohridski", Museum of Paleontology and Historical Geology, 1504 Sofia, Bulgaria; \\ E-mail: stefka19491@gmail.com
}

\section{Произхо на бесарабските варовици с Nubecularia novorossica от Североизточна България}

\section{Елена Колева-Рекалова ${ }^{1}$, Стефка Даракчиева ${ }^{2}$}

${ }^{1}$ Геологически институт, Българска академия на науките, ул. „Акад. Г. Бончев“, бл. 24, София 1113

${ }^{2}$ Софийски университет „Св. Климент Охридски“, Музей по палеонтология и исторична геология, София 1504

\begin{abstract}
The Central and Eastern Paratethys Basins were connected and the joint Sarmatian Sea (Paratethys) appeared after the end of the Badenian. It was separated from the Mediterranean and Indopacific Ocean. As a result, the seawater salinity dropped and mass production of a few euryhaline groups (mainly benthic foraminifera, molluscs, and ostracods) with increasing endemisms developed at the beginning of the Sarmatian (s.l. and s.s.). The fauna and paleoenvironments (facies) were similar throughout the Paratethys. The Bessarabian limestones (referred to the Odartsi Formation) are composed almost entirely of the endemic foraminifera Nubecularia novorossica Karrer \& Sinzow, 1877 and exposed on the territory of Northeastern Bulgaria are described in the present article. Six sections were examined, and it was found that the limestones were predominantly stratified and only in the upper parts of some sections were dome-shaped. Two varieties Nubecularia novorossica solitaria and Nubecularia novorossica nodula were defined and they are the predominant rock-forming constituent. The most appropriate environmental conditions for the occurrence, blooming and accumulation in the initial sediments of the Nubecularia novorossica tests were identified. Comparison with the findings of this nubeculariid from other Sarmatian sections reveals that the stratified limestones studied are rigid mainly due to the presence of cement, whereas abundant encrusting and microbial organisms in the dome-shaped bodies contributed to the formation of their rigid framework.
\end{abstract}

Keywords: Nubecularia novorossica Karrer \& Sinzow, 1877, Bessarabian limestone, Odartsi Formation, Northeastern Bulgaria.

Резюме. В края на Баденския век Централният и Източният Паратетиски басейн се свързват, в резултат на което възниква Сарматското море (Паратетис). То е било отделено от Средиземно море и от Световния океан. Поради тази причина, в началото на Сарматския век (s.l. и s.s.) солеността на морската вода намалява и започва масовата поява на ендемични еврихалинни форми (главно бентосни фораминифери, молюски и остракоди). Фауната и обстановките на седиментация са били идентични в целия Паратетис. В настоящата статия се описват варовици с бесарабска възраст (отнесени към Одърската свита), изградени почти изцяло от ендемичния вид Nubecularia novorossica Karrer \& Sinzow, 1877, които се разкриват на територията на Североизточна България. Изследвани са шест разреза, като е установено, че варовиците са предимно стратифицирани и само в горните части на някои разрези имат куполовидна форма. Определени са две вариететни форми - Nubecularia novorossica solitaria и Nubecularia novorossica nodula, които са преобладаващият скалообразуващ компонент. Установени са най-подходящите условия за появата, разцвета и натрупването в първичните утайки на Nubecularia novorossica. Сравнението с находки на този нубекуларид от други сарматски разрези разкрива, че изследваните стратифицирани варовици са здрави главно поради наличието на цимент, докато в куполовидните тела се срещат обилни инкрустиращи и микробни организми, които са отговорни за тяхната здравина.

Ключови думи: Nubecularia novorossica Karrer \& Sinzow, 1877, бесарабски варовици, Одърска свита, Североизточна България.

\section{Introduction}

At the end of the Badenian (at the age of $12.65 \mathrm{Ma}$ according to Palcu et al., 2015, 2017) the Central and Eastern (Euxinian-Caspian) Paratethyan Basins were separated from the Mediterranean and Indopacific Ocean. At the beginning of the Sarmatian, these two basins were connected through opening of the Barlad gateway (Palcu et al., 2015, 2017) and joint Sarmatian Sea extended from the Vienna 
Basin to the Aral Sea (Schneider et al., 2013) (Fig. 1) and the Kopetdagh region in Turkmenistan (Popov et al., 2006).

The Sarmatian s.l. (Eastern Paratethys) is subdivided into three regional substages: Volhynian, Bessarabian and Khersonian (Fig. 2). These substages were named after the regions or localities in which were described: Volhynian for deposits with Ervilia described in Volhynia, Bessarabian for beds with Nubecularia described in Bessarabia, and Khersonian for beds with Mactra caspia described in the surroundings of Kherson (Simionescu, 1903). The Sarmatian s.s. (Central Paratethys) is subdivided into Lower and Upper (Harzhauser, Piller, 2004) and corresponds to the upper part of the Serravallian of the Mediterranean time scale and to the Volhynian and lower part of the Bessarabian (Fig. 2).

The water salinity dropped and almost all Badenian stenohaline organisms (radiolarians, planktonic foraminifera, corals and echinoderms) became extinct at the Badenian/Sarmatian boundary. Mass production of a few euryhaline groups (mainly benthic foraminifera, molluscs, and ostracods) with increasing endemisms developed (Rögl, 1999). The fauna and paleoenvironments (facies) were similar throughout the Paratethys (Rögl, 1999) during the Sarmatian (s.l. and s.s.).

As an example of endemism was the unique sessile benthic foraminifera Nubecularia novorossica Karrer \& Sinzow, 1877, which flourished simultaneously in the Sarmatian Sea (Fig. 1), and in some cases it was a rock-forming constituent (Belokrys, 1976; Boda, 1979; Vernyhorova, 2015). The same nubeculariid represents a rock-forming component of the Bessarabian limestones (referred to the Odartsi Formation) that crops out on the territory of Northeastern Bulgaria (Koleva-Rekalova, Darakchieva, 2017; Koleva-Rekalova, 2019) (Fig. 3a, b). The main objective of the present study is to elucidate the origin of the Bessarabian limestones (with Nubecularia novorossica) as well as to correlate them with coeval findings from other localities of the epicontinental Sarmatian Paratethys.

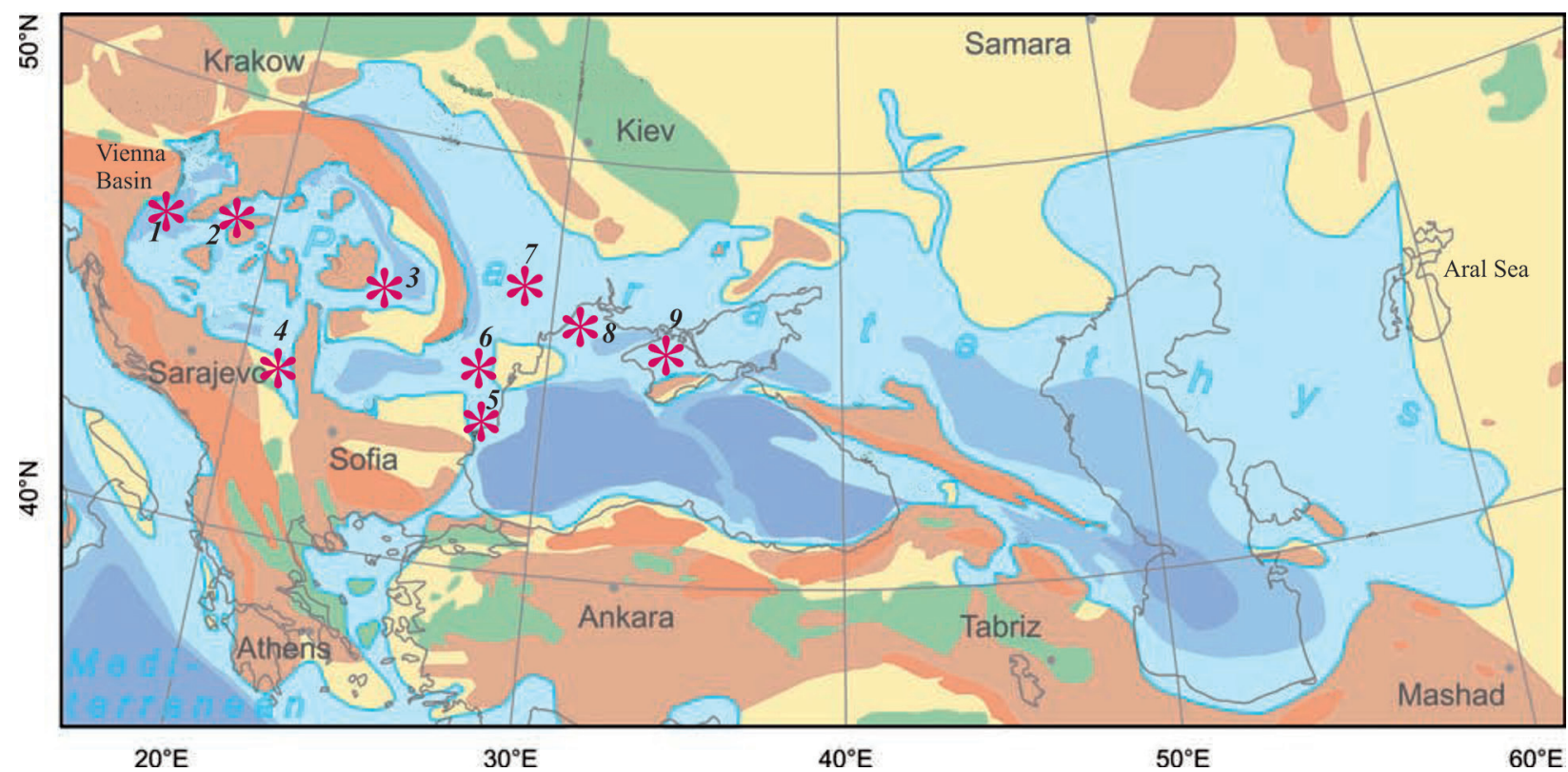

Fig. 1. Location of the Paratethys Sea during the Sarmatian s.s. (= Volhynian and Early Bessarabian s.l.) after Schneider et al. (2013), with additions: occurrences of Nubecularia novorossica (red stars)

1, Vienna and Styrian Basins, Austria (Harzhauser, Piller, 2004; Piller, Harzhauser, 2005), 2, Zsámbék Basin, Hungary (Boda, 1979; Cornée et al., 2009), 3, Transylvanian Basin, Romania (Suciu, 2005), 4, Pannonian Basin, Serbia (Gagić, Mitrović, 1994; 1995), and in the Eastern Paratethys: 5, Northeastern Bulgaria (Koleva-Rekalova, Darakchieva, 2017; Koleva-Rekalova, 2019), 6, Southern Dobrogea, Romania (Munteanu, Munteanu, 1997), 7, Moldova (Karrer, Sinzow, 1876; Bobrinskaya, 2011), 8, Southern Ukraine (Belokrys, 1976; Vernyhorova, 2015), 9, Crimean Peninsula (Vernyhorova, 2015)

Фиг. 1. Местоположение на Паратетиското море през Сармата s.s. (= Волин и Ранен Бесараб s.l.) по Schneider et al. (2013), с допълнения: находки на Nubecularia novorossica (червени звезди)

1 - Виенски и Щирийски басейн, Австрия (Harzhauser, Piller, 2004; Piller, Harzhauser, 2005), 2 - Zsámbék басейн, Унгария (Boda, 1979; Cornée et al., 2009), 3 - Трансилвански басейн, Румъния (Suciu, 2005), 4 - Панонски басейн, Сърбия (Gagić, Mitrović, 1994; 1995) и в Източния Паратетис: 5 - Североизточна България (Koleva-Rekalova, Darakchieva, 2017; KolevaRekalova, 2019), 6 - Южна Добруджа, Румъния (Munteanu, Munteanu, 1997), 7 - Молдова (Karrer, Sinzow, 1876; Bobrinskaya, 2011), 8 - Южна Украйна (Belokrys, 1976; Vernyhorova, 2015), 9 - Кримски полуостров (Vernyhorova, 2015) 


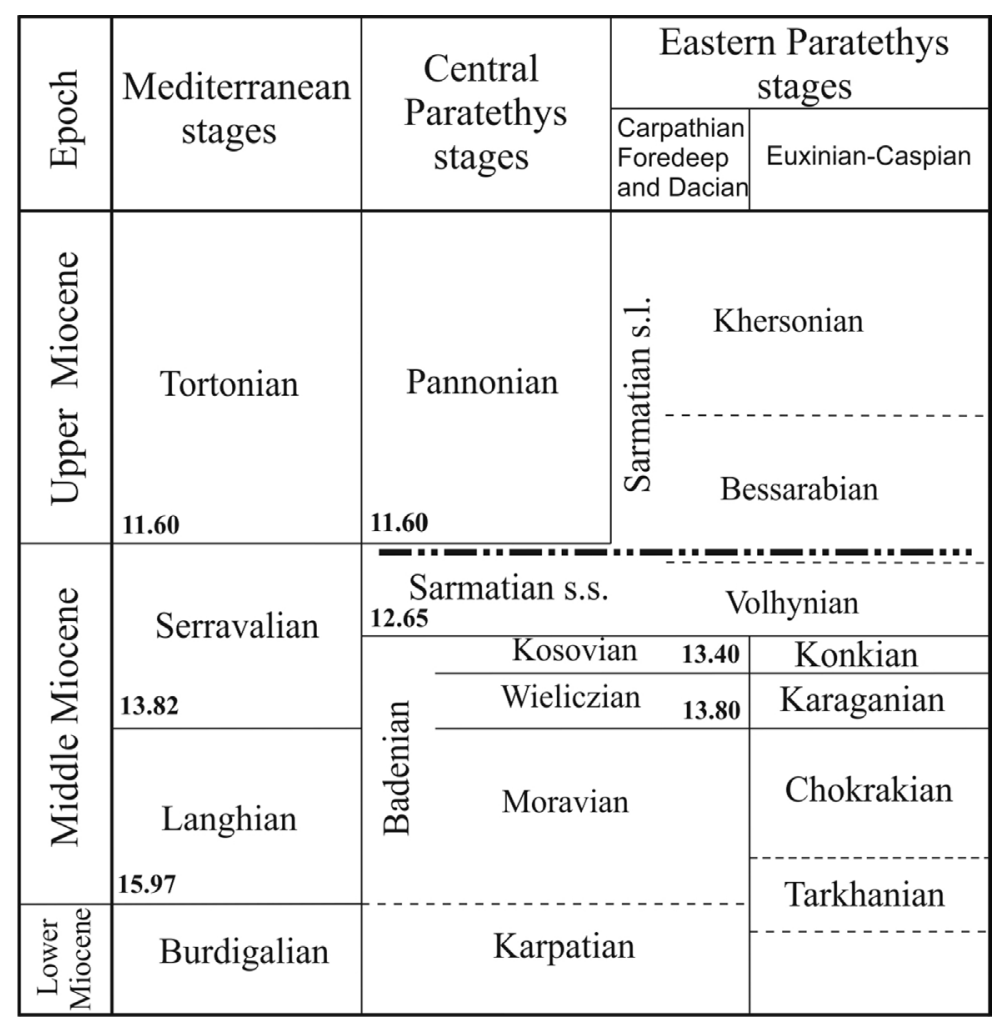

Fig. 2. Correlation chart of the Miocene regional stages of the Central and Eastern Paratethys with Mediterranean stages after Palcu et al. (2017) with some modifications and addition of the location of Nubecularia novorossica Realm (thick broken line)

Фиг. 2. Корелационна схема на миоценските регионални етажи от Централния и Източния Паратетис със Средиземноморските етажи по Palcu et al. (2017) с частични изменения и ареал на съществуване на Nubecularia novorossica (дебела прекъсната линия)

\section{Geological setting and lithostratigraphy}

During the Miocene (including the Sarmatian) the Varna-Dobrogea Bay of the Euxinian-Caspian Basin (Eastern Paratethys) was situated on the territory of Northeastern Bulgaria (Kojumdgieva, Popov, 1981; Popov et al., 1986) (Fig. 3a-c). It was active from the Tarchanian Age to the Khersonian Sub-age. Popov et al. (1986) introduced the following structural-palaeogeographic areas in the bay: I, South-Dobrogea Strait; II, Marginal Area of the Varna-Balchik Depression (III); IIIa, Varna part of the depression; IIIb, Balchik part of the depression. The South-Dobrogea Strait was an uplifted area, flooded by the sea during the Tarchanian, Early Volhynian, Middle Bessarabian, and Middle Khersonian. The Marginal Area was a shallow shelf surrounding the Varna-Balchik Depression from the west and north. Probably, the Varna-Balchik Depression was only the westernmost part of a larger depression, the main part of which was situated in the Black Sea (Ivanov et al., 2007).

Popov and Kojumdgieva (1987) introduced seven formal and two informal lithostratigraphic units for the Miocene of Northeastern Bulgaria. The following lithostratigraphic units are included in the studied here region: Euxinograd, Franga, Odartsi, Topola, and Karvuna Formations (Fig. 3b). The investigated limestone with Nubecularia novorossica is the main constituent of the Odartsi Formation. The chronstratigraphic range of the Odartsi Formation is a part of the Bessarabian (Plicatiforma fittoni molluscs Zone and Flintina tutkowski foraminifera Zone (Kojumdgieva et al., 1989; Darakchieva, 1989) (Fig. 4).

\section{Material and methods}

The materials came from two old sections - Odartsi and Kamen Bryag (Koleva-Rekalova, Darakchieva, 2002) and four new outcrops at Kaliakra Cape, Bolata Bay, Tyulenovo and Shabla Cape (KolevaRekalova, Darakchieva, 2017; Koleva-Rekalova, 2019) (Fig. 3b). The studied limestones are hard and strongly lithified and Nubecularia novorossica is investigated only in thin-sections. About 35 thinsections of limestones from studied sections were 


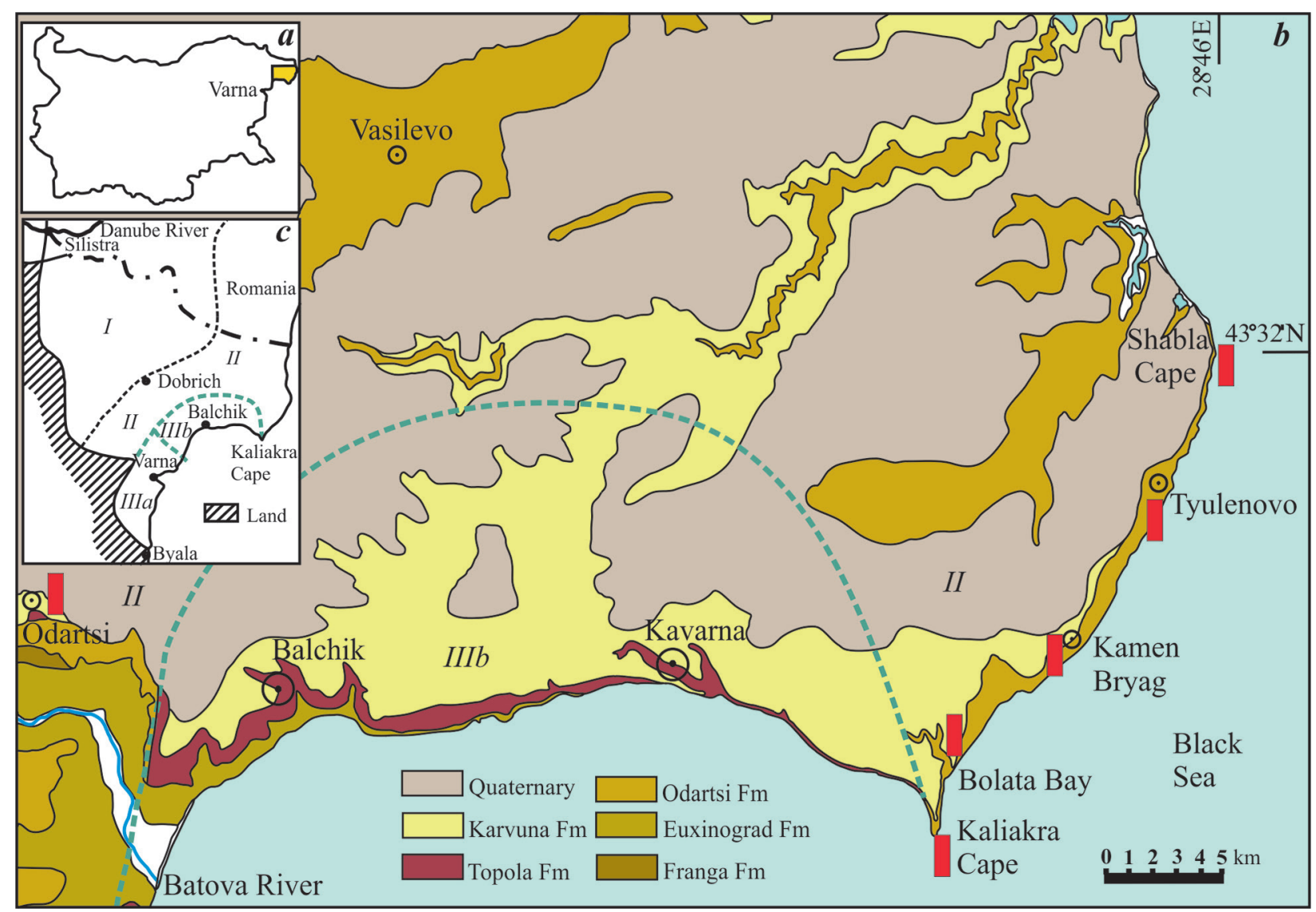

Fig. 3. $a$, position of the studied region on the territory of Bulgaria; $b$, geological map on scale 1:500 000 (after Cheshitev, Kanchev, 1989) of the same region (a part of Northeastern Bulgaria), with addition of the location of the investigated sections (red rectangles); $c$, sketch map of the structural-palaeogeographic areas in the Varna-Dobrogea Bay of the EuxinianCaspian Basin during the Neogene (after Popov et al., 1986)

I, South-Dobrogea Strait; II, Marginal (Shelf) Area of the Varna-Balchik Depression (III), IIIa, Varna part of the depression, $I I I b$, Balchik part of the depression (green broken line in $b$ and $c$ )

Фиг. 3. $\boldsymbol{a}$ - местоположение на изследвания район на територията на България; $\boldsymbol{b}$ - геоложка карта в М 1:500 000 (по Cheshitev, Kanchev, 1989) на сыщия район (част от Североизточна България), с добавено разположение на изследваните разрези (червени правоъгълници); $c$ - схематична карта на структурно-палеогеографските области на Варненско-Добруджанския залив на Евксино-Каспийския басейн през Неогена (по Popov et al., 1986)

$I$ - Южнодобруджански пролив, II - крайбрежна (шелфова) част на Варненско-Балчишката депресия (III), III - Варненска част на депресията, ІІІб - Балчишка част на депресията (зелена прекъсната линия в $b$ и $c$ )

investigated using light transmitting microscope "Zeiss Axioscope 40". Photomicrographs were taken with a ProgRes GT3 digital camera.

\section{Brief description of the studied sections}

\section{Section Odartsi (Fig. 5a)}

The sediments of the section are described and sampled in the scarp of the road from the village of Batovo to the village of Odartsi (Fig. 3b). It is the type section for the Odartsi Formation (Popov, Kojumdgieva, 1987).

The basement of the section consists of pale gray sands with a bed thickness of $1.0-2.0 \mathrm{~cm}$ and total thickness of about $2.0 \mathrm{~m}$ (Franga Formation). At the base of the Odartsi Formation an alternation (3.5 m thick) of pale gray sandy limestones and sandy shelly limestones occurs. The bed thickness is $10.0-15.0 \mathrm{~cm}$. The same alternation (with a total thickness of about $1.0 \mathrm{~m}$ ) covers a $9.5 \mathrm{~m}$ soil area. Above them, white sandy shelly limestones $(10.0-15.0 \mathrm{~cm}$ thick) with a total thickness of $1.0 \mathrm{~m}$ crop out. At the base, the shells are 1.5-2.0 cm long, and upwards their size gradually decreases. There is a soil interval of about $8.0 \mathrm{~m}$. The section continues with white foraminiferal-ooidal limestones (containing Nubecularia novorossica) showing bed thickness from 15.0 to a maximum of $30.0 \mathrm{~cm}$ (total thickness of $5.4 \mathrm{~m}$ ). Among them three levels with small caverns filled with red pelitic materials (terra 


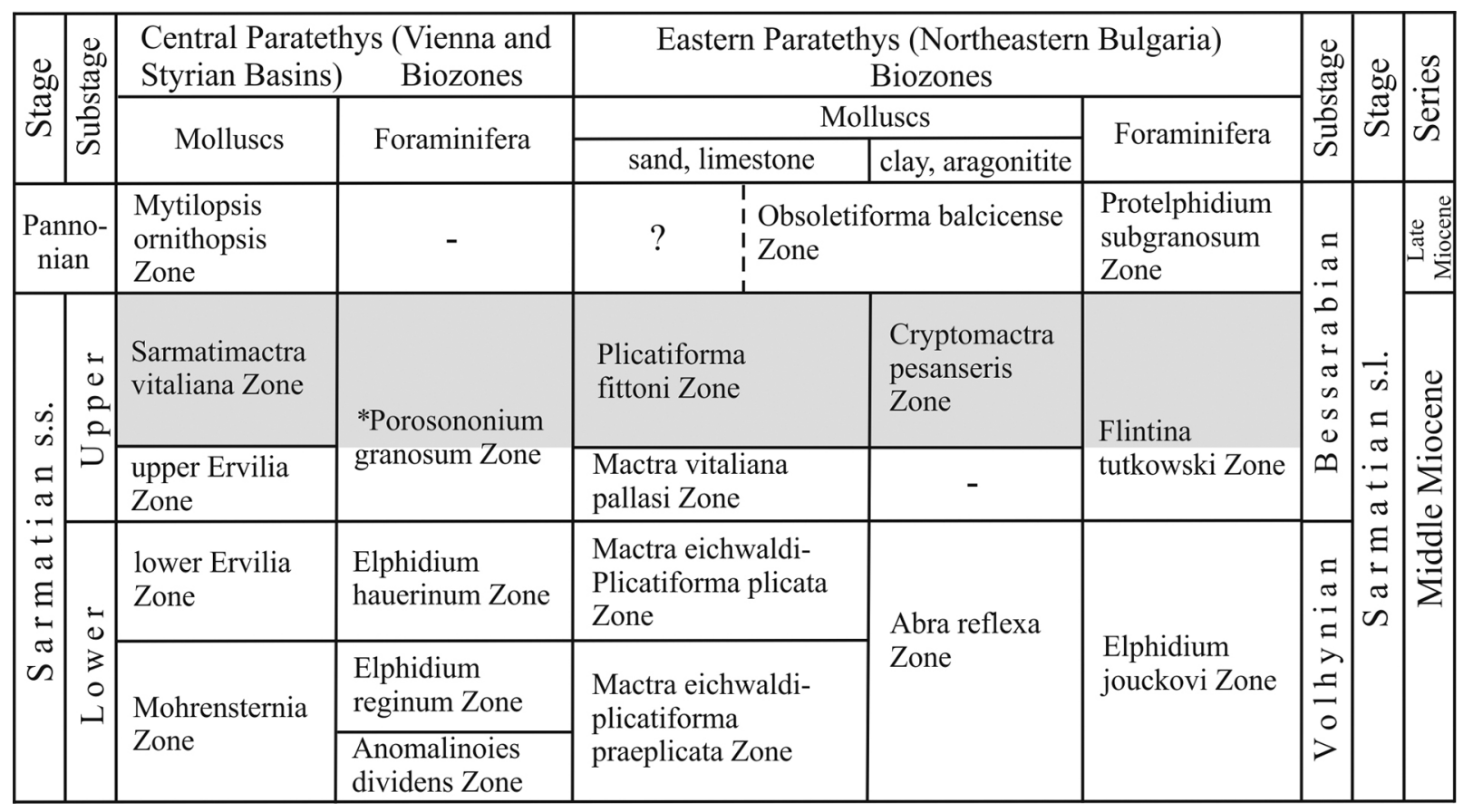

Fig. 4. Biostratigraphy of the Central Paratethys (for the Vienna and Styrian Basins) during the Sarmatian s.s. (after Harzhauser, Piller, 2004) and the Eastern Paratethys (Northeastern Bulgaria) during the Volhynian and Bessarabian (after Kojumdgieva et al., 1989; Darakchieva, 1989), with Nubecularia novorossica Realm (in gray color)

* Porosononium granosum Zone correlates with Spirolina austrica Zone of the Zsámbék Basin, Hungary (Görög, 1992)

Фиг. 4. Биостратиграфия на Централния Паратетис (за Виенския и Щирийския басейн) през Сармата s.s. (по Harzhauser, Piller, 2004) и Източния Паратетис през Волина и Бесараба (по Kojumdgieva et al., 1989; Darakchieva, 1989), с ареала на съществуване на Nubecularia novorossica (в сив цвят)

* Зоната Porosononium granosum се корелира със зоната Spirolina austrica в Zsámbék басейн, Унгария (Görög, 1992)

rossa) are observed. The term "terra rossa" is used for red soils derived from the hard limestone (Durn, 2003). Above this interval white to creamy foraminiferal limestones (with Nubecularia novorossica) exist. The bed thickness is $10.0-20.0 \mathrm{~cm}$ and the total thickness is $10.6 \mathrm{~m}$. At the base, middle, and top parts of this interval, layers and lenses of gray calcareous silts (with an individual thickness of 15.0 to $20.0 \mathrm{~cm}$ ) are observed. The section ends with white micrite limestones, which are referred to the Topola Formation (Popov, Kojumdgieva, 1987). All described limestones have horizontal stratification, with the exception of some foraminiferal-ooidal limestones that possess cross-stratification. The limestones of the Odartsi Formation are enriched in molluscs - zone Plicatiforma fittoni (Kojumdgieva et al., 1989) (Fig. 4).

\section{Section Kamen Bryag (Fig. 5b)}

This section is located from the sea level up to the cliff to the eastern end of the village of Kamen Bryag (Fig. 3b).

At the basement of the section, there is a $2.0 \mathrm{~m}$ thick strongly karstified limestone zone that con- tains many caverns, lenses and pockets filled with red pelitic materials (terra rossa). Above it, creamy shelly limestones with a thickness of 5.0-7.0 cm are exposed, which alternate with thin interbeds representing karstified zones, filled with red terra rossa. After a 2.0 soil interval, the section continues with white to creamy foraminiferal limestones (containing Nubecularia novorossica) with a total thickness of $26.5 \mathrm{~m}$. Their individual thickness usually is $10.0-15.0 \mathrm{~cm}$ and they possess horizontal stratification. In the lower $4.5 \mathrm{~m}$ of this interval, the thickness of the beds is $2.0-3.0 \mathrm{~cm}$ and the limestones are interbedded with thin intercalations filled with red pelitic materials. At the top of the section, the beds are also thinner $(5.0-10.0 \mathrm{~cm}$ thick). All limestones contain bivalvian shells, usually up to $1.5 \mathrm{~cm}$ long, only at the base of the interval they reach up to $2.5-3.0 \mathrm{~cm}$ (Plicatiforma fittoni Zone) (Fig. 4).

\section{Section Kaliakra Cape (Fig. 6a)}

This section is located in the front of Kaliakra Cape (Figs 3b, 6a).

From the sea level upwards there is an interval of about $3.0 \mathrm{~m}$ thick, composed of gray-white fo- 
raminiferal limestones (containing Nubecularia novorossica) with individual bed thickness of $5.0-15.0 \mathrm{~cm}$. Above it, the limestones become thinner - up to $5.0 \mathrm{~cm}$ thick (total thickness is $3.0 \mathrm{~m}$ ).

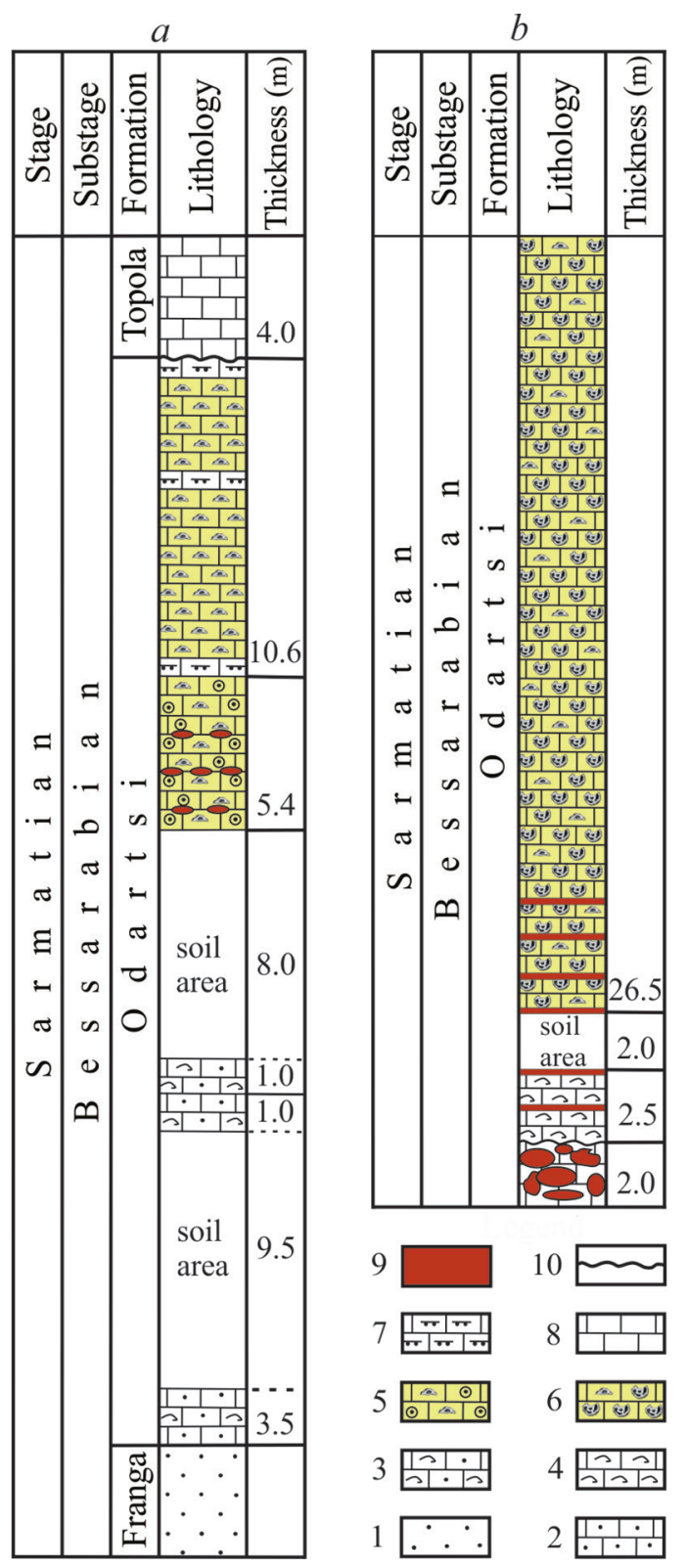

Fig. 5. Lithostratigraphic columns of the sections: $a$, Odartsi; $b$, Kamen Bryag

1 , sand, 2, sandy limestone, 3 , sandy shelly limestone, 4 , shelly limestone, 5, foraminiferal-ooidal limestone with Nubecularia novorossica, 6, foraminiferal limestone consisting mainly of Nubecularia novorossica, 7 , silt, 8, micrite limestone, 9, terra rossa, 10, discontinuity

Фиг. 5. Литосратиграфски колонки на разрезите: $a$ Одърци; $\boldsymbol{b}$ - Камен бряг

1 - пясък, 2 - песъчлив варовик, 3 - песъчливо-черупчест варовик, 4 - черупчест варовик, 5 - фораминиферно-ооиден варовик с Nubecularia novorossica, 6 - фораминиферен варовик, изграден главно от Nubecularia novorossica, 7 - алеврит, 8 - микритен варовик, 9 - тера роса, 10 - прекъсване
They are interbedded with thin intercalations filled with red terra rossa. In the next 5.0-m interval the limestones are strongly altered and contain many red pelitic materials. Stratigraphically higher, the section continues with thin-bedded limestones with a total thickness of about $5.0 \mathrm{~m}$. The foraminiferal limestones with Nubecularia novorossica are covered with stromatolite-trombolite levels.

\section{Section Bolata Bay (Fig. 6b)}

The section Bolata Bay is located in the Bolata Bay, north of the Kaliakra Cape (Fig. 3b). It comprises about $20.0 \mathrm{~m}$ of limestones with $\mathrm{Nubecu}$ laria novorossica (Fig. 6b). In the lower half of the section, the limestones are with horizontal stratification and show varying bed thickness from 2.0 5.0 to $20.0-50.0 \mathrm{~cm}$. Upwards they become more massive and thicker with a vaguely expressed horizontal stratification. On weathered surface, limestones possess creamy to ochre and red coloration (Fig. 6b, c). The small white nearly spherical bodies represent larger Nubecularia novorossica tests (Fig. 6c).

\section{Section Tyulenovo (Fig. 6d)}

The section near the village of Tyulenovo (14 m thick) is composed predominantly of stratified limestones with individual bed thickness varying from 2.0 to $10.0 \mathrm{~cm}$, rarely up to $20.0 \mathrm{~cm}$. The limestones are strongly weathered and karstified. They are creamy to reddish in color in cases where they contain red pelitic materials (terra rossa) resulting from the weathering. On the weathered limestone surfaces the Nubecularia novorossica tests are well visible (Fig. 6e). Other macrofossils are represented by rare bivalvian shells and single gastropods. Many caves of various sizes and diversified karst forms exist. At the top of the section, dome-shaped bodies about $2.0 \mathrm{~m}$ high and varying in width from 1.0 to $2.0 \mathrm{~m}$ are located. They are composed of creamy in color limestones, which are less weathered but foraminifera tests (Nubecularia novorossica) are observed on their upper surfaces.

\section{Section Shabla Cape (Fig. 6f)}

The section is located near the Monument of the Soviet pilots (Fig. 6f, red asterisk). Only domeshaped bodies, the same as those from the uppermost part of the section Tyulenivo, are exposed here. The dome-shaped body height is up to $2.5 \mathrm{~m}$ and their width varies from 1.0 to $3.0 \mathrm{~m}$. 

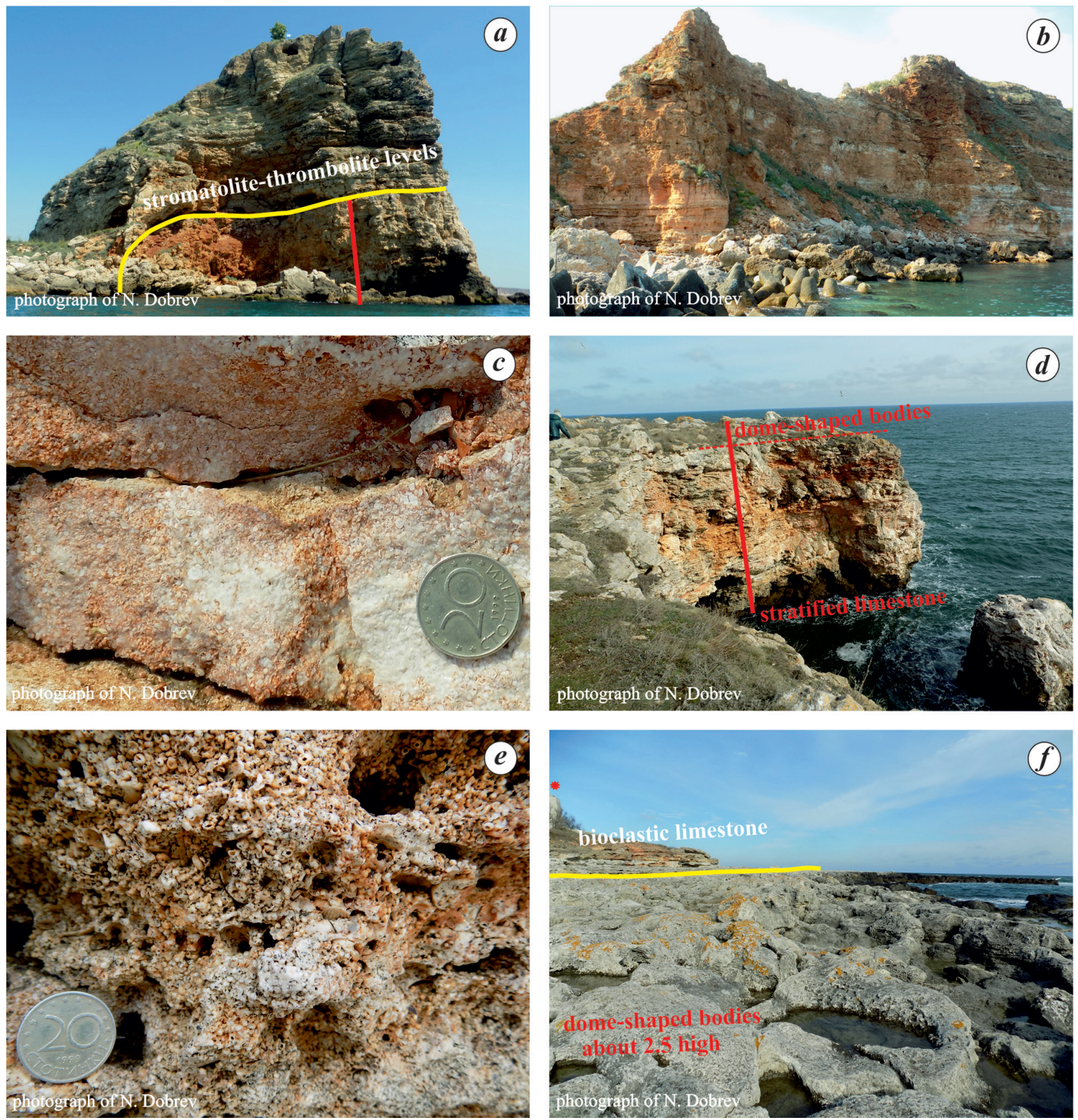

Fig. 6. $a$, section Kaliakra Cape (red line) covered by stromatolite-thrombolites; $b$, section Bolata Bay; $c$, section Bolata Bay, on the weathered limestone surface are observed larger Nubecularia novorossica tests; $d$, section Tyulenovo (red line), stratified limestones and dome-shaped bodies in the uppermost part; $e$, section Tyulenovo, Nubecularia novorossica tests on the weathered limestone surface; $f$, section Shabla Cape, located near the Monument of the Soviet pilots (red asterisk) composed of dome-shaped bodies, around $2.5 \mathrm{~m}$ high, covered by bioclastic limestone

Фиг. 6. $\boldsymbol{a}$ - разрез нос Калиакра (червена линия) покрит от строматолити-тромболити; $\boldsymbol{b}$ - разрез залив Болата; $c$ - разрез залив Болата, на изветрялата повърхност на варовика се наблюдават по-големи черупки на $\mathrm{Nubecularia}$ novorossica; $d$ - разрез Тюленово (червена линия), стратифицирани варовици и куполовидни тела в най-горната част; $\boldsymbol{e}$ - разрез Тюленово, черупки на Nubecularia novorossica върху изветрялата повърхност на варовик; $f$ - разрез нос Шабла, разположен близо до паметника на съветските пилоти (червена звездичка), съставен от куполовидни тела с височина около $2,5 \mathrm{~m}$, покрити с биокластични варовици

\section{Results}

The preliminary study on the limestones in the lower parts of the sections Kaliakra Cape and Bolata Bay (Fig. 6a, b) (referred to the Odartsi Formation) revealed that they were mainly composed of special nubeculariid Nubecularia novorossica Karrer \& Sinzow, 1877 (Koleva-Rekalova, Darakchieva, 2017). This led to a re-evaluation of the Bessarabian limestones from two sections near the villages 
of Odartsi and Kamen Bryag (Koleva-Rekalova, Darakchieva, 2002) (Fig. 5), and to investigated other two sections - Tyulenovo and Shabla Cape (Fig. 6d, f).

Karrer and Sinzow (1876) first described $\mathrm{Nu}$ becularia novorossica in the Bessarabian sand around Kishinev. They divided it into three varieties - Nubecularia solitaria, Nubecularia nodula, and Nubecularia deformis. Cushman (1933) introduced Nubecularia novorossica Karrer \& Sinzow as a new genus - Sinzowella Cushman, in honor of Dr. J. Sinzow. Bogdanovich (1952) suggested four forms of Nubecularia novorossica: solitaria with the flattened test, nodulus with the ring-like test, crustaformis with the crusty-like shape, and subnodulus with unwinding ring-like shape. Boda (1979), when studied the Upper Sarmatian sediments in the vicinity of Páty (Hungary), divided Sinzowella novorossica also into four forms: solitaria, nodula, deformis (Fig. 7), subnodulosa. The tests of this nubeculariid are attached with calcareous, imperforate, porcelaneous and thick walls (Loeblich, Tappan, 1988).

The microscopic examination of thin-sections of the limestones comprising Nubecularia novorossi$c a$ from all studied sections reveals that nubeculariids are only of forma (variety) solitaria and forma (variety) nodula. Forma solitaria is represented by a single flattened test with a slightly concave lower surface and convex upper part, 0.5-1.0 $\mathrm{mm}$ long in cross-sections (Plate Ia-d, g) and forma nodula (up to $2.0 \mathrm{~mm}$ in diameter) with ring-like shape in longitudinal-sections (Plate Ic-h).
Two intervals composed of foraminiferal-ooidal and foraminiferal limestones are recognized in the section Odartsi (Fig. 5a, in light yellow coloration). According to the textural classification of Dunham (1962), these limestones represent grainstones (composed of 55-60\% allochems and $40-45 \%$ cement). Two types of cement are recognized - thin bladed isopachous (around allochems) and later drusy filling the pore spaces in the foraminiferalooidal limestones (Plate Ia). The ooids (normal and superficial) slightly predominate. They are usually spheroidal and ellipsoidal in shape and their sizes rarely exceed $1.0 \mathrm{~mm}$. Ooids with radial-fibrous and tangential cortices occur, and their nuclei are commonly small foraminifera, recrystallized bioclasts, quartz grains, and in rare cases Nubecularia novorossica solitaria (Plate Ia). Other allochems are represented by Nubecularia novorossica solitaria, small foraminifera, recrystallized bivalvian shell bioclasts, single bryozoan fragments, micrite peloids, micrite intraclasts and quartz (from single grains to about $20 \%$ ). In the foraminiferal limestones, besides small foraminifera Nubecularia novorossica solitaria tests are observed (Plate $\mathrm{Ib}$ ). The nubeculariid sizes are less than $1.0 \mathrm{~mm}$. Bivalvian shell fragments, single ooids and quartz grains are recognized, too (Plate $\mathrm{Ib}$ ). There are also two types of cement as in foraminiferal-ooidal limestones. Cross-sections of Elphidium, Flintina, and many Miliolidae were defined in studied thin-sections (Koleva-Rekalova, Darakchieva, 2002). According to the detailed study of the foraminiferal composition of the limestones, Darakchieva (1989,

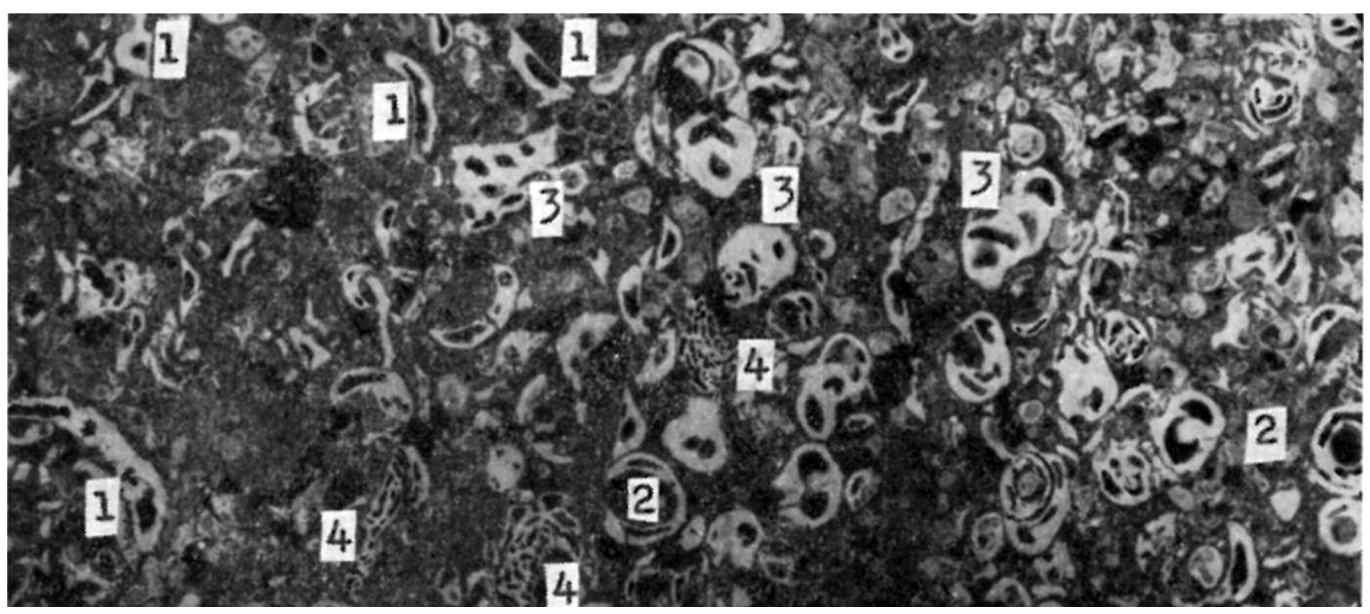

Fig. 7. Polished slab of limestone containing three forms of Sinzowella novorossica

1, solitaria, 2, nodula, 3, deformis, 4, Sinzowella caespitosa (after Boda, 1979, author's Table I, top picture, Páty, Honey Valley, $\mathrm{N}=\sim 9 \mathrm{x})$

Фиг. 7. Полиран образец на варовик, съдържащ три форми на Sinzowella novorossica 1 - solitaria, 2 - nodula, 3 -deformis, 4 - Sinzowella caespitosa (по Boda, 1979, авторска таблица I, горна фотоснимка, Пати, Медената долина, $\mathrm{N}=\sim 9 \mathrm{x})$ 
1990) referred them to the foraminiferal zone Flintina tutkowski (Fig. 4), which was characterized by rich assemblage of foraminifera with typical Middle Sarmatian age.

The section Kamen Bryag consists mainly of foraminiferal limestones (grainstones) (Fig. 5b, in light yellow colouration). The nubeculariids predominate over the small foraminifera. There is a relative abundance with Nubecularia novorossica nodula and some tests reach to $2.0 \mathrm{~mm}$ in diameter (Plate Ic). Nubecularia novorossica solitaria also exists (Plate Ic, d). Other observed constituents are bivalvian shell bioclasts, single gastropod shells and sporadic bryozoan fragments. The cement is two types - isopachous and drusy (Plate Ic, d). No terrigenous components are detected as in Odartsi section. Cross-sections of small foraminifera were defined in the thinsections: Triloculina, Quinqueloculina, Pseudotriloculina, Nonion and indefinable Miliolidae (Koleva-Rekalova, Darakchieva, 2002). These limestones were also referred to Flintina tutkowski Zone (Darakchieva, 1989).

The studied limestones with nubeculariids are localized in the lower part of the section Kaliakra Cape (Fig. 6a). These limestones are strongly recrystallized and only some longitudinal and crosssections of Nubecularia novorossica nodula and Nubecularia novorossica solitaria can be recognized (Plate Ie). As a result of the secondary recrystallization, the calcite mosaics are composed of crystals of highly varying sizes. The recrystallization has obliterated the limestone texture, but we can refer them to the foraminiferal grainstones.

The limestones with nubeculariids are characteristic of the section Bolata Bay (Fig. 6b). Some larger tests are visible on the weathered surface of the limestones (Fig. 6c). These limestones also represent foraminiferal grainstones. Nubecularia novorossica nodula (Plate If, g) prevails over Nubecularia novorossica solitaria (Plate Ig). Small foraminifera (strongly recrystallized tests of Porosononion and Ammonia beccarii), single gastropod shells, as well as ooids (Plate Ig), occur. Isopachous and drusy cements exist.

The dome-shaped bodies at the section Cape Shabla (Fig. 6f) mainly consist of tests of Nubecularia novorossica nodula (Plate Ih) and rarely of Nubecularia novorossica solitaria. Microbial peloids (composed of cyanobacteria) and encrusting red algae, bryozoans and sporadic serpulids are also found in some thin sections. Relics of bladed isopachous cement around some allochems can be observed (Plate Ih).

The limestones from the section Tyulenovo have not been microscopically examined. However, macroscopic observations of the weathered surface of the stratified limestone (Fig. 6e), as well as of the dome-shaped bodies, show that they are composed almost entirely of Nubecularia novorossica nodula and rarely of Nubecularia novorossica solitaria (Koleva-Rekalova, 2019).

\section{Discussion}

\section{Origin of the Bessarabian limestone with Nubecularia novorossica}

Many occurrences of the limestones containing the Lower Bessarabian (= Upper Sarmatian s.s.) $\mathrm{Nu}$ becularia novorossica exist in the geological record (Fig. 1). The most important ones were described in: 1. Vienna Basin (with Eisenstadt-Sopron Subbasin) and Styrian Basin (Harzhauser, Piller, 2004; Piller, Harzhauser, 2005); 2. Zsámbék Basin (Hungary) (Boda, 1979; Cornée et al., 2009); 3. Transylvanian Basin (Romania) (Suciu, 2005); 4. Pannonian Basin (Serbia) (Gagić, Mitrović, 1994, 1995) and in the Eastern Paratethys: 5. Northeastern Bulgaria (Koleva-Rekalova, Darakchieva, 2017; Koleva-Rekalova, 2019); 6. Southern Dobrogea (Romania) (Munteanu, Munteanu, 1997); 7. Moldova (Karrer, Sinzow, 1876; Bobrinskaya, 2011); 8. Southern Ukraine (Belokrys, 1976; Vernyhorova, 2015); 9. Crimea (Vernyhorova, 2015); etc. This fact demonstrates that during the same period in the Sarmatian Sea there were favorable biotic and abiotic factors for the blooming of this unique nubecularrid.

At the beginning of the Sarmatian salinity dropped, all stenohaline organisms became extinct and a mass production of a few groups with increasing endemisms developed (Rögl, 1999). The Sarmatian fauna was classically regarded as brackish water one (Papp, 1956; Boda, 1979; Kojumdgieva, 1969; Iljina et al., 1976; Friebe, 1994; Vrsaljko et al. 2006; Kováć et al., 2008; etc.). According to Kojumdgieva (1969), the salinity of seawater during the Volhynian (= Early Sarmatian s.s.) was 14$15 \%$ for the Euxinian-Caspian Basin and 16-17\%o for the Vienna-Pannonian Basin. Iljina et al. (1976) considered that the salinity of the Euxinian-Caspian Basin during the Volhynian was 14-18\%o. Temniskova-Topalova (1994) based on diatomaceous analysis of the Bessarabian clayey sediments determined salinity for the the Varna-Dobrogea Bay of the Euxinian-Caspian Basin as about 15\%. Görög (1992) inferred a salinity of 18 to $25 \%$ or for the consolidated brackish-water condition in the Zsámbék Basin (Hungary). Principally, Ager (1963) defined the salinity of the brackish water as follows: oligihaline $(0.5-3.0 \%)$, mesohaline $(3.0-16.5 \%)$ and polyhaline (16.5-30.0\%). Over the past two dec- 

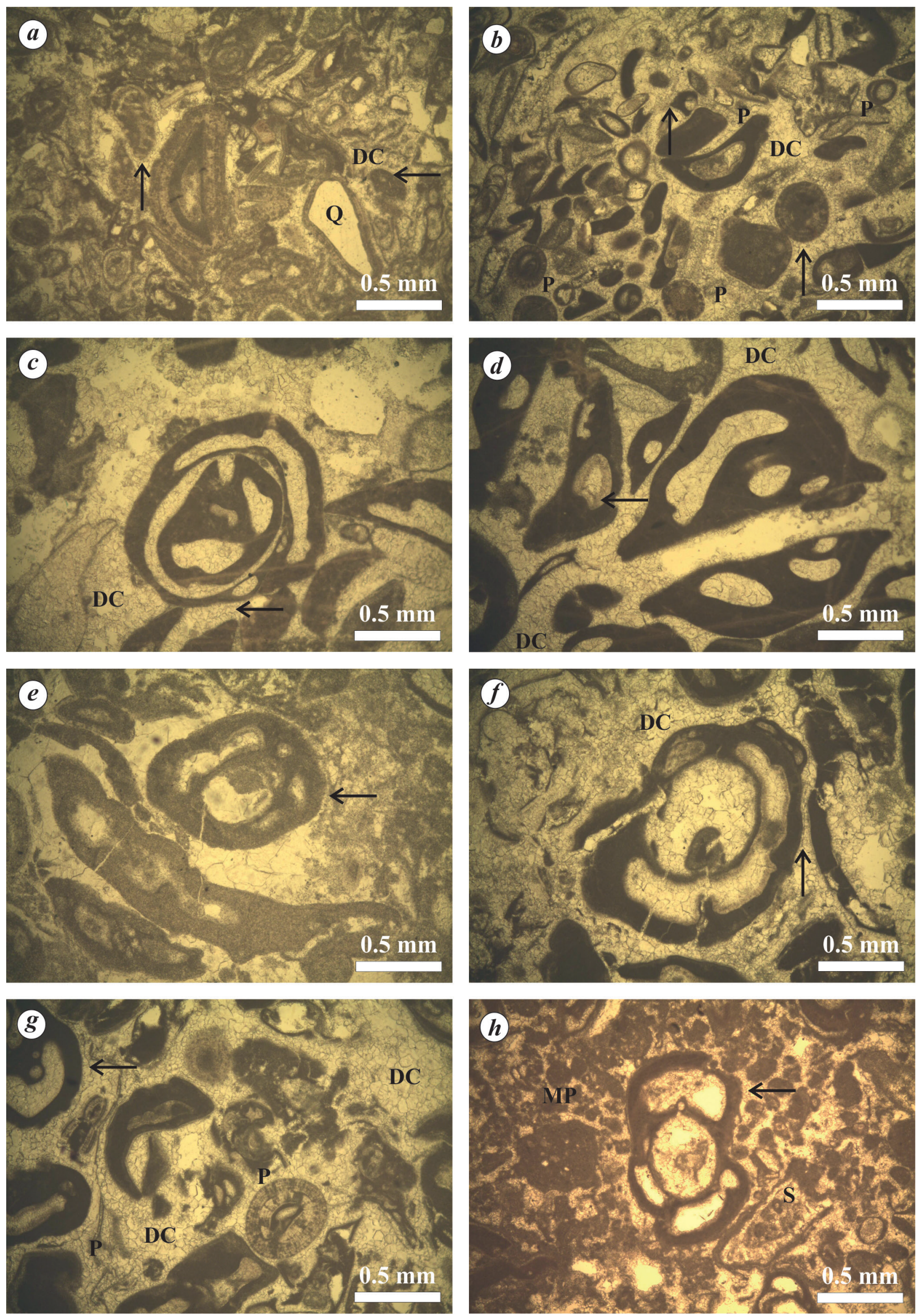
a. Ooid with Nubecularia novorossica solitaria nucleus (centre) and another ooid with quartz nucleus (Q), single superficial ooids, micrite peloids (with sizes less than $0.2 \mathrm{~mm}$ ), micrite intraclasts (up to $1.0 \mathrm{~mm}$ in size), small foraminifera, recrystallized bioclasts and terrigenous components (predominantly quartz grains), relics of bladed isopachous cement around some allochems (black arrows) and drusy calcite mosaics (DC); foraminiferal-ooidal limestone (grainstone), thin-section 8-6-I, II N, section Odartsi.

b. Nubecularia novorossica solitaria (centre), some ooids, small foraminifera, bioclasts with thin micrite envelope, single terrigenous components (quartz grains), bladed isopachous cement around allochems (black arrows), in smaller pores are observed polygonal boundaries (P) between them and drusy cement (DC) in larger pore spaces; foraminiferal limestone (grainstone), thinsection 10-7-I, II N, section Odartsi.

c. Nubecularia novorossica nodula (centre), Nubecularia novorossica solitaria (right) and single recrystallized bivalvian bioclasts, relics of bladed isopachous cement around some allochems (black arrow) and drusy calcite mosaics (DC); foraminiferal limestone (grainstone), thin-section 20-12-III, II N, section Kamen Bryag.

d. Cross-sections of Nubecularia novorossica nodula and Nubecularia novorossica solitaria, more preserved bladed isopachous cement in the foraminiferal chambers (black arrow) and drusy calcite cement (DC); foraminiferal limestone (grainstone), thinsection 22-15-III, II N, section Kamen Bryag.

e. Mainly longitudinal and cross-sections of Nubecularia novorossica nodula and Nubecularia novorossica solitaria, relics of bladed isopachous cement around some allochems (black arrow) and secondary recrystallized sparry calcite mosaics; recrystallized foraminiferal limestone (grainstone), thin-section IV-2, II N, section Kaliakra Cape.

f. Nubecularia novorossica nodula about $2.0 \mathrm{~mm}$ in length, bladed isopachous cements around allochems (black arrow) and drusy calcite mosaics (DC); foraminiferal limestone (grainstone), thin-section B-2, II N, section Bolata Bay.

g. Nubecularia novorossica solitaria (centre), some parts of Nubecularia novorossica nodula (left) and a small ooid, bladed isopachous crusts (cement) around allochems (black arrow), in smaller pore spaces are observed polygonal (P) boundaries between them and drusy calcite cement (DC) filling the rest part of the pores; foraminiferal limestone (grainstone), thin-section B-2, II N, section Bolata Bay.

h. Nubecularia novorossica nodula (centre), microbial peloids (MP) and cross-section of serpulid (S), relics of bladed isopachous cement around some allochems (black arrow); foraminiferal limestone (grainstone), thin-section Sh-02, II N, section Shabla Cape.

\section{ТАБЛИЦА I}

а. Ооид с ядро от Nubecularia novorossica solitaria (център) и друг ооид с ядро от кварцово зърно, единични зачатъчни ооиди, микритни пелоиди (с размери под $0,2 \mathrm{~mm}$ ), микритни интракласти (с размери до $1,0 \mathrm{~mm})$, малки фораминифери, прекристализирали биокласти и теригенни компоненти (предимно кварцови зърна), реликти от листовидна изопахитна спойка около някои алохеми (черни стрелки) и друзови калцитни мозайки (DC); фораминиферно-ооиден варовик (грейнстоун), дюншлиф 8-6-I, II N, разрез Одърци.

b. Nubecularia novorossica solitaria (център), няколко ооида, малки фораминифери, биокласти с тънка микритна обвивка, единични теригенни компоненти (кварцови зърна), листовидна изопахитна спойка около алохемите (черни стрелки), в по-малките пори се наблюдават полигонални граници (Р) между тях и друзова спойка (DC) в по-големите порови пространства; фораминиферен варовик (грейнстоун), дюншлиф 10-7-I, II N, разрез Одърци.

c. Nubecularia novorossica nodula (център), Nubecularia novorossica solitaria (дясно) и единични прекристализирали бивалвийни биокласти, реликти от листовидна изопахитна спойка около някои алохеми (черна стрелка) и друзови калцитни мозайки (DC); фораминиферен варовик (грейнстоун), дюншлиф 20-12-III, II N; разрез Камен бряг.

d. Напречни прерези на Nubecularia novorossica nodula и Nubecularia novorossica solitaria, по-запазена листовидна изопахитна спойка в камерките на фораминиферите (черна стрелка) и друзова калцитна спойка (DC); фораминиферен варовик (грейнстоун), дюншлиф 22-15-III, II N, разрез Камен бряг.

е. Главно надльжни и напречни прерези на Nubecularia novorossica nodula и Nubecularia novorossica solitaria, реликти от листовидна изопахитна спойка около някои алохеми (черна стрелка) и вторично прекристализирали спаритни калцитни мозайки; прекристализирал фораминиферен варовик (грейнстоун), дюншлиф IV-2, II N, разрез нос Калиакра.

f. Nubecularia novorossica solitaria с дължина около $2,0 \mathrm{~mm}$, листовидна изопахитна спойка около алохемите (черна стрелка) и друзовидни калцитни мозайки (DC); фораминиферен варовик (грейнстоун), дюншлиф B-2, II N, разрез залив Болата. g. Nubecularia novorossica solitaria (център), няколко части от Nubecularia novorossica nodula (ляво) и един мальк ооид, листовидни изопахитни обвивки (спойка) около алохемите (черна стрелка), в по-малките порови пространства се наблюдават полигонални (P) граници между тях и друзовидна калцитна спойка (DC), запълваща останалата част от порите; фораминиферен варовик (грейнстоун), дюншлиф В-2, II N, Одърска свита, разрез залив Болата.

h. Nubecularia novorossica nodula (център), микробиални пелоиди (MP) и напречен пререз на серпулид (S), реликти от листовидна изопахитна спойка около някои алохеми (черна стрелка); фораминиферен варовик (грейнстоун), дюншлиф Sh-02, II N, разрез нос Шабла.

ades, several authors suggested that the Sarmatian Sea was, in fact, more or less marine, even with hypersaline episodes (Pisera, 1996; Piller, Harzhauser, 2005; Harzhauser, Piller, 2007; Koubová, Hudáčková, 2010; Tóth et al., 2010; etc.). Piller and Harzhauser (2005) explained this fact with the presence of a highly productive carbonate factory (oolite shoals, the mass occurrence of thick-shelled molluscs and larger foraminifera, including also Nubecularia novorossica). The salinity values have 

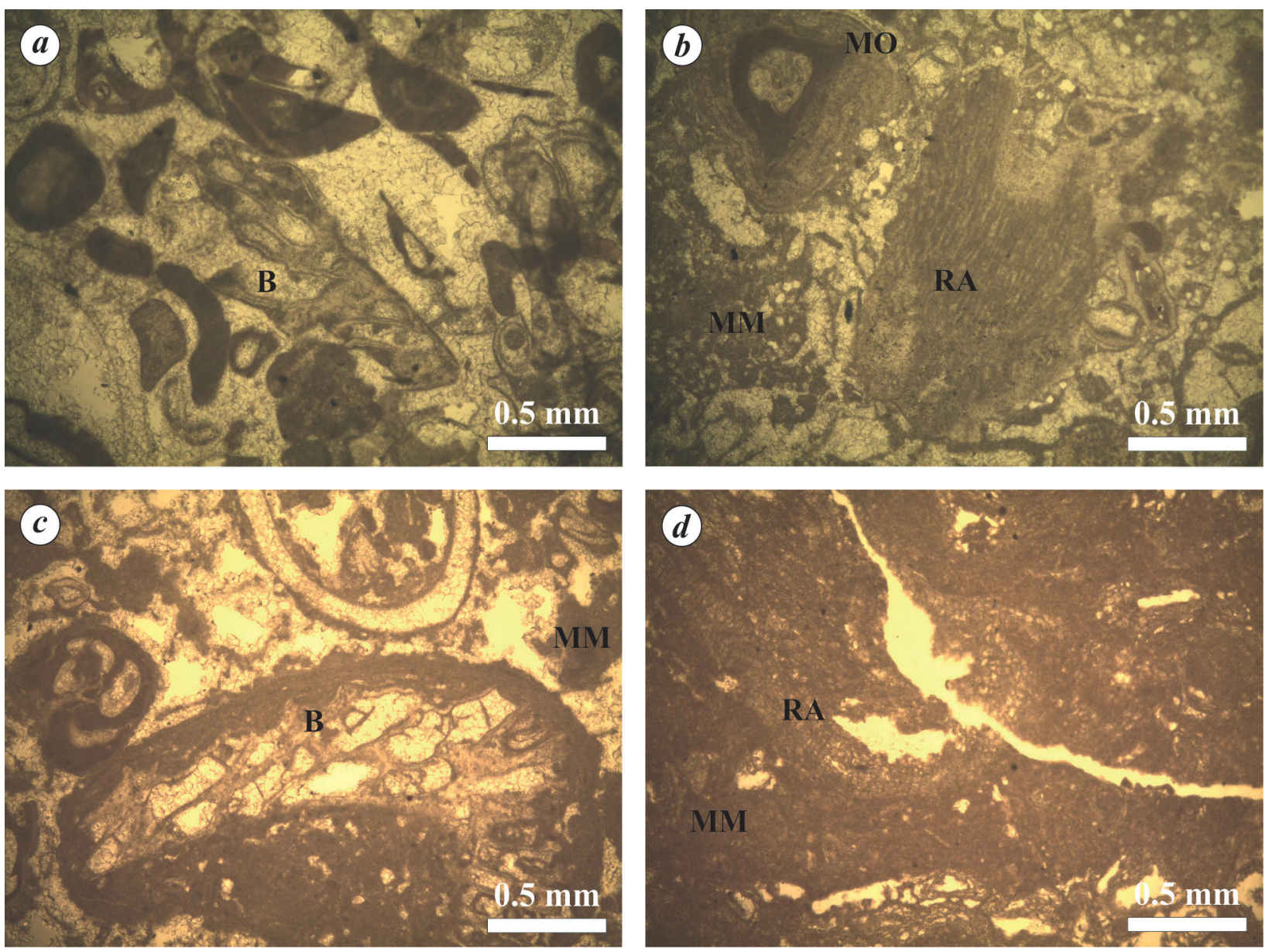

\section{PLATE II}

a. Bryozoan fragment (B), several cross-sections of Nubecularia novorossica, sporadic recrystallized shell bioclasts (down left), cement; stratified foraminiferal limestone (grainstone), thin-section 13-8-III, II N, section Kamen Bryag.

b. Red alga (RA), microbial oncoid (MO) with Nubecularia novorossica nucleus and microbial masses (MM), cement; stratified foraminiferal limestone (grainstone), thin-section B-1, II N, section Bolata Bay.

c. Nubecularia novorossica nodula (left), bryozoan fragment (B), microbial masses (MM) and a recrystallized shell bioclast (top centre), cement; foraminiferal limestone (grainstone), thin-section Sh-02, II N, dome-shaped body, section Shabla Cape.

d. Red algae (RA) and microbial masses (MM); thin-section Sh-03, II N, dome-shaped body, section Shabla Cape.

\section{ТАБЛИЦА II}

а. Фрагмент от бриозоя (В), няколко напречни пререза от Nubecularia novorossica, спорадични прекристализирали биокласти от черупки (долу ляво), спойка; стратифициран фораминиферен варовик (грейнстоун), дюншлиф 13-8-III, II N, разрез Камен бряг.

b. Червено водорасло (RA), микробиален онкоид (МО) с ядро от Nubecularia novorossica и микробиални маси (ММ); стратифициран фораминиферен варовик (грейнстоун), дюншлиф В-1, II N, разрез залив Болата.

c. Nubecularia novorossica nodula (ляво), фрагмент от бриозоя (В), микробиални маси (ММ) и един биокласт от прекристализирала черупка (горе център), спойка; фораминиферен варовик (грейнстоун), дюншлиф Sh-02, II N, куполовидно тяло, разрез нос Шабла.

d. Червени водорасли (RA) и микробиални маси (MM); дюншлиф Sh-03, II N, куполовидно тяло, разрез нос Шабла.

had an impact on the form, size and amount of the nubecularrid studied. For example, the foraminiferalooidal and foraminiferal limestones from the section Odartsi contain terrigenous components (quartz, feldspar, rock lithoclasts) in various amounts from single grains to $5.0 \%$, sporadically to $20.0 \%$ (Koleva-Rekalova, 1997a). Most likely, this clastic material was transported to the basin by fresh-water 
river inputs that diluted sea water. The presence of ooids (Plate 1a, b) indicates high-energy environment. Under these conditions only Nubecularia novorossica solitaria tests with sizes less than $1.0 \mathrm{~mm}$ (Plate 1b) could have existed. Conversely, in the foraminiferal limestones from the sections Kamen Bryag, Kaliakra Cape, Bolata Bay, Tyulenovo and Shabla Cape there are no terrigenous components and ooids are scarce. Both Nubecularia novorossica solitaria and Nubecularia novorossica nodula (Plate Ic-h) are observed here as a rock-forming constituent with sizes that sometimes reach up to $2.0 \mathrm{~mm}$. The absence of terrigenous input and sporadic ooids proves that the nubeculariids lived and thrived here in polyhaline brackish water with a greater salinity (about $25 \%$ or slightly more) and in a relatively quiet energy regime.

The climate has also had an influence on the flourishing of the nubeculariids. Ivanov et al. (2007), based on pollen data, concluded that the climate conditions were relatively stable for the territory of Northeastern Bulgaria in the lower part of Bessarabian (= Upper Sarmatian s.s). The climate was seasonal with temperatures of the warmest months of $24.7-27.3^{\circ} \mathrm{C}$ and of the coldest months of ca. 5.0 $7.0^{\circ} \mathrm{C}$. The annual precipitations varied from 823 to 1206 (1308) $\mathrm{mm}$. The climate was warm and facilitating biotic (including nubeculariids) and abiotic carbonate precipitation (predominantly as cement). Most probably, the drying of the climate occured during the begining of the Late Miocene when the massive aragonite sediments were accumulated in the Balchic part of the Varna-Balchic Depression (Koleva-Rekalova, 1994) as well as dolomites in Southern Ukraine (Belokrys, 1967). The change from a warm to a drier climate may have occurred after the isolation of the Eastern Paratethys from the Central Paratethys (11.6-11.3 Ma) as a result of the tectonic uplift of the Carpathian Mountains (Palcu et al., 2019 and references therein).

Didkovskyi (1961) commented that nubeculariids were characteristic of the shallow water facies where they could be in large quantities (rock-forming component). Maisuradze (1980) also stated that the development of the nubeculariids took place under shallow water conditions, abundantly populated by underwater vegetation (nutrient enriched), on a solid substrate. Miclea (2017) concluded that the Sinzowella assemblage in the Borod Basin, westernmost extension of the Pannonian Basin, was found in oxygenated near-shore environment, with high energy zones. Most of the limestones containing Nubecularia novorossica are related to ooidal limestones: in the Vienna and Eisenstadt-Sopron Basins (Upper Sarmatian Skalica Formation) (Harzhauser, Piller, 2004; 2009), the Styrian Basin (Friebe, 1994; Harzhauser, Piller 2004); the Zsámbék Basin
(Hungary) (Görög, 1992; Cornée et al. 2009), the Kolumbara Basin (southernmost part of the Pannonian Basin) in Serbia (Gagić, Mitrović, 1995), the Varna-Dobrogea Bay of the Euxinian-Caspian Basin (this study, section Odurtsi), etc. Phleger (1960) determined that ooidal limestones were formed in the inner turbulent zone at 20.0-30.0 m depth. According to Khrischev (1971), the most optimal bathymetric conditions for the formation of ooids exist immediately below the tidal zone at a depth of about $1.8 \mathrm{~m}$. In the western part of the Vienna Basin, Harzhauser and Piller (2009) described more than $20 \mathrm{~m}$ thick Upper Sarmatian carbonate platform with oolite shoals and foraminiferal (nubeculariid) bioconstructions, formed in very shallow marine settings. Because the Bessarabian (Upper Sarmatian s.s.) limestones also contain a rich mollusc fauna, Lukender et al. (2011) concluded that mollusc assemblages from the Central and Eastern Paratethys were characteristic of the near-shore and shallow environments. Presumably, the studied nubeculariids lived and flourished in oxygenated near-shore or shallow water environments, riched in nutrients, at a depth from 1.8 to not more than $20.0-30.0 \mathrm{~m}$, on a solid substrate.

Microscopic examination manifested that around allochems (mainly nubeculariids and rarely ooids, bivalve fragments, small foraminifera, gastropods, bryozoans, etc.) there is a isopachous bladed crust cement (Plate Ia-g). In some smaller pore spaces polygonal boundaries between them are observed (Plate Ib, d, g). According to Chatalov (2000) and Flügel (2004), bladed crusts represent first cement generation, formed in the marine phreatic realm (shallow subtidal zone). The major prerequisite for marine cementation is the supersaturation of the waters with respect to calcium carbonate. Increasing temperature and salinity and decreasing $\mathrm{CO}_{2}$ levels lead to higher saturation (Chatalov, 2000). Larger pores are filled by secondary drusy type cement (Plate Ia-g).

\section{Correlation with coeval findings from other localities of the Sarmatian Paratethys}

Frieble (1994) described two Upper Sarmatian serpulid-bryozoan-foraminiferal biostromes (with a thickness of $0.5-1.0$ and $1.5 \mathrm{~m}$ ) in the Styrian Ba$\sin$ (Austria). The serpulids, bryozoa and encrusting foraminifera Sinzowella caespitosa (Steinmann), as well as microbial mats, formed a rigid framework. Nubecularia novorossica tests are rare and encrusted. Piller and Harzhauser (2005) commented that in the Eisenstadt-Sopron Basin as well as in the NW Styrian Basin were formed foraminifera-coralline algalmicrobial build-ups (bioherms) up to $20.0 \mathrm{~m}$ width. 
Foraminifera are exclusively represented by sessile nubeculariids (Sinzowella). Small hemispherical lenses or extensive crusts with nubeculariids (Sinzowella novorossica), red algae and bryozoans, associated with diversified mollusc shell accumulations were investigated in the Zsámbék Basin (Cornée et al., 2009). In Galician (Moldova) and Borysthen (Crimea) Gulfs of the Paratethys, the algal-Nubecularia bioherms in the Vasilievo and the upper part of the Novomoskovsk beds (horizons) were formed during the Bessarabian (= Upper Sarmatian s.s.). Five species of red algae in symbiosis with $\mathrm{Nu}$ becularia novorossica, and with the presence of bryozoans and cyanobacteria, formed both nodules $(5.0-40.0 \mathrm{~cm}$ in diameter) and round loaf-shaped bioherms up to 2.0-3.0 m high (Goncharova, Rostovtseva, 2009).

Compared with the above examples, the stratified limestones of the studied sections contain predominantly Nubecularia novorossica solitaria and Nubecularia novorossica nodula tests (Plate I) as a rock-forming component. They resemble those described by Boda (1979) in the vicinity of Páty (Hungary) (Fig. 7), but without Sinzowella deformis and encrusting Sinzowella caespitosa. In our samples bryozoan fragments are rare (Plate IIa), red algae and microbial (cyanobacterial) masses and ooids are sporadic (Plate IIb). However, in dome-shaped bodies (investigated microscopically in the section Shabla Cape) apart from Nubecularia novorossica tests, larger amounts of bryozoan bioclasts (Plate II c), red algae and microbial masses are found (Plate IId), and single cross-sections resemble serpulids (Plate Ih).

Most likely, during the Early Bessarabian, appropriate environmental conditions (discussed above) were created for occurrence, blooming and accumulation of the Nubecularia novorossica tests on the shallow shelf of the Varna-Balchik Depression (Fig. 1c) that was located in the present-day territory of Northeastern Bulgaria (Fig. 1a, b). Their development was so numerous and rapid that they were able to form sediments of large thickness, for example, the thickness of resulted limestones in the section Kamen Bryag is $26.5 \mathrm{~m}$ (Fig. 5b). The accumulation of the tests was almost continuous, with minor discontinuities when the bed surfaces were formed. Probably, for this reason encrusting fossils such as bryozoans and red algae as well as microbial masses are rare in stratified limestones studied. However, at some moment there has been a change in the favorable habitat conditions of the nubecularrids, for example, due to a tectonic event (elevation?) and/or an increase in temperature. Thus, their development decreased and even stopped. In the upper parts of the sediment containing foraminifera began to increase encrusting (bryozoans, serpulids and red algae) and microbial organisms, which were more adaptable to the newly created environment. They helped to create a rigid framework and to form dome-shaped bodies, observed in the upper part of the section Tyulenovo and section Shabla Cape.

The stratified limestones that contain Nubecularia novorossica tests as a rock-forming component are rigid mainly due to the generation of primary (isopachous) cement around the allochems and later pore-filling (drusy) cement. Although the role of the encrusting organisms is not significant, these limestones can be attributed to biostromes. The domeshaped bodies represent typical bioherms.

\section{Conclusions}

Many findings of the limestones containing Sarmatian Nubecularia novorossica exist in the geological record. The Bessarabian limestones composed of the same Nubecularia novorossica as a rock-formining constituent are exposed and have been studied in 6 sections on the territory of Northeastern Bulgaria: Odartsi, Kaliakra Cape, Bolata Bay, Kamen Bryag, Tyulenovo, and Shabla Cape. These limestones are referred to the Odartsi Formation. The chronostratigraphic range of the formation is a part of the Bessarabian (Plicatiforma fittoni molluscs Zone and Flintina tutkowski foraminifera Zone). The limestones are predominantly well stratified and only at the uppermost part of the section Tyulenovo and the section Shabla Cape are observed as domeshaped bodies.

The microscopic examination of the limestones reveals that nubeculariids are represented by two of four varieties: Nubecularia novorossica solitaria and Nubecularia novorossica nodula. Nubecularia novorossica is also known as Sinzowella Cushman. Two types of cement are recognized: first generation isopachous bladed cement around the allochems (mostly nubeculariids and rarely ooids, bivalve fragments, small foraminifera, gastropods, bryozoans, etc.) and secondary drusy type cement that fills the pore spaces.

Based on the previously published data, the most appropriate environmental conditions for the occurrence, blooming and accumulation of the Nubecularia novorossica tests have been clarified. The nubeculariids lived and thrived in polyhaline brackish water with salinity of about $25 \%$ or slightly more and in a relatively quiet energy regime (sections Kaliakra Cape, Bolata Bay, Kamen Bryag, Tyulenovo). Diluted sea water and higher energy conditions diminished the sizes and amount of Nubecularia novorossica tests (section Odartsi). The climate was seasonal, but warm and facilitating biotic (including nubecularrids) and abiotic carbon- 
ate precipitation (mainly as cement). The studied nubeculariid lived on solid substrate in oxygenated near-shore or shallow water environments (riched in nutrients) at a depth from 1.8 to not more than 20.0-30.0 m (shallow subtidal zone).

The comparison with some other Sarmatian limestone findings containing the same nubeculariid has shown that in the stratified limestones studied here, the encrusting organisms (as bryozoan and red algae) and microbial masses are in a subordinate amount. The limestone rigid appearance is mainly due to the existence of cement. But when the favorable habitat conditions of the nubeculariids were changed, there was an increase in the presence of red algae, bryozoans, microbes and even serpulids, which led to the formation of rigid dome-shaped bodies (bioherms).

Acknowledgements: This work has been carried out in the framework of the National Science Program "Environmental Protection and Reduction of Risks of Adverse Events and Natural Disasters", approved by the Resolution of the Council of Ministers № 577/17.08.2018 and supported by the Ministry of Education and Science (MES) of Bulgaria (Agreement № D01-230/06.12.2018).

\section{References}

Ager, D. V. 1963. Principles of Paleoecology. An Introduction to the Study of How and Where Animals and Plants Lived in the Past. International Series in the Earth Sciences. New York, San Francisco, Toronto, London, McGraw-Hill Book Company, Inc., $371 \mathrm{p}$.

Belokrys, L. S. 1967. Has there been any freshening of the Sarmatian Sea in Southern Ukraine? - J. Sov. Geologia, 7, 97-110 (in Russian).

Belokrys, L. S. 1976. The Sarmatian of the Southern Ukrainian SSR. - In: Stratigraphy of the Cenozoic of the Northern Black Sea Region and Crimea. Dnepropetrovsk, DGU, 3-21 (in Russian).

Bobrinskaya, O. G. 2011. Foraminifera complexes of Sarmatian deposits (based on drilling materials) of Moldova. Buletinul Institutului de Geologie și Seismologie al AȘM, 2, 58-71.

Boda, J. 1979. Nubecularia-félék (Foraminifera) kőzetalkotó mennyiségben a hazai szarmatában. - Földtani Közlöny, 109, 2, 288-293.

Bogdanovich, A. K. 1952. Miliolida and Peneroplida: Fossil Foraminifera of USSR. Trudy VNIGRI, 64, 338 p. (in Russian).

Chatalov, A. 2000. Marine phreatic cements in the Triassic limestones from the Western Balkanides. - Geologica Balc., 30, 1-2, 33-48.

Cheshitev, G., I. Kanchev. 1989. Geological Map of P. R. Bulgaria on Scale 1:500 000. Sofia, Committee of Geology, Department of Geophysical Prospecting and Geological Mapping.

Cornée, J.-J., P. Moissette, J.-P. Saint Martin, M. Kázmér, E. Tóth, Á. Görög, A. Dulai, P. Müller. 2009. Marine carbonate systems in the Sarmatian (Middle Miocene) of the Central Paratethys: the Zsámbék Basin of Hungary. - Sedimentology, 56, 1728-1750.

Cushman, J. A. 1933. Some new foraminiferal genera. - Contrib. Cushman Lab. Foram. Res., 9, 32-38.

Darakchieva, S. 1989. Foraminiferal zonation of the Miocene in Northeastern Bulgaria. - Palaeont., Stratigr., Lithol., 27, 31-43 (in Bulgarian with English abstract).
Darakchieva, S. 1990. The Foraminifera of the Miocene Series in Northeastern Bulgaria. - In: Microfossils in Bulgarian Stratigraphy. Sofia, Bulg. Geol. Soc., 59-64 (in Russian).

Didkovskyi, V. J. 1961. Milliolids of the Neogene Sediments of the Southwestern Part of the Russian Platform. Kiev, Academy of Sciences of USSR, 172 p. (in Ukrainian).

Dunham, R. J. 1962. Classification of carbonate rocks according to depositional texture. - In: Classification of Carbonate Rocks. Am. Assoc. of Petrol. Geol., 1, 108-171.

Durn, G. 2003. Terra rossa in the Mediterranean Region: parent materials, composition and origin. - Geologia Croatica, 56, $1,83-100$.

Flügel, E. 2004. Microfacies of Carbonate Rocks. Berlin, Springer, $976 \mathrm{p}$.

Friebe, J. G. 1994. Serpulid-bryozoan-foraminiferal biostromes controlled by temperate climate and reduced salinity. $-\mathrm{Fa}$ cies, 30, 51-62.

Gagić, N., S. Mitrović. 1994. Microfossil communities from Middle Sarmatian sediments of Belgrade Area. - Ann. Géol. Penins. Balk., 58, 2, 183-195 (in Serbian with English abstract).

Gagić, N., S. Mitrović. 1995. Microfossil communities from Middle Sarmatian carbonate sediments in borehole Olm95/89 (Skobalj), Kolubara Basin. - Ann. Géol. Penins. Balk., 59, 2, 221-236 (in Serbian with English abstract).

Goncharova, I. A., Y. V. Rostovtseva. 2009. Evolution of organogenic carbonate buildups in the Middle through Late Miocene of the Euxine-Caspian Basin (Eastern Paratethys). - Paleontol. J., 43, 8, 866-876.

Görög, Á. 1992. Sarmatian foraminifera of the Zsámbék Basin, Hungary. - Ann. Univ. Sci. Budap., Sect. Geol., 29, 31-153.

Harzhauser, M., W. E. Piller. 2004. Integrated stratigraphy of the Sarmatian (Upper Middle Miocene) in the western Central Paratethys. - Stratigraphy, 1, 1, 1-22.

Harzhauser, M., W. E. Piller. 2007. Benchmark data of a changing sea - palaeogeography, palaeobiogeography and events in the Central Paratethys during the Miocene. - Palaeogeogr., Palaeoclimatol., Palaeoecol., 253, 8-31. 
Harzhauser, M., W. E. Piller. 2009. Molluscs as a major part of subtropical shallow-water carbonate production - an example from a Middle Miocene oolite shoal (Upper Serravallian, Austria). - Intern. Assoc. Sedimentol. Spec. Publ., 42, $185-200$

Iljina, L. B., L. A. Nevesskaja, N. P. Paramonova. 1976. Regularities in the Development of Mollusks in the Brackishwater Basins of the Neogene of Eurasia. Proceedings of the Paleontological Institute of the Academy of Sciences of USSR, 155, 288 p. (in Russian).

Ivanov, D. A., A. R. Ashraf, V. Mosbrugger. 2007. Late Oligocene and Miocene climate and vegetation in the Eastern Paratethys area (Northeast Bulgaria), based on pollen data. - Palaeogeogr., Palaeoclimatol., Palaeoecol., 255, 342-360.

Karrer, F., J. Sinzow. 1876. Über das Auftreten des Foraminiferen-Genus Nubecularia im sarmatischen Sande von Kischenew. - Sitzungsber. Akad. Wiss., Math. Nat., 74, 272-284.

Khrischev, K. 1971. Recent carbonate sedimentation and its significance for the palaeographic reconstructions of ancient limy complexes. - Rev. Bulg. Geol. Soc., 32, 2, $163-$ 174 (in Bulgarian with English abstract).

Kojumdgieva, E. 1969. Formes hemisténohalines marines du Sarmatian Inférieur en Bulgarie de Nord-Quest. - Bull. Geol. Inst., Ser. Paleontol., 18, 5-12 (in Bulgarin with French abstract).

Kojumdgieva, E., N. Popov. 1981. Régions structuro-paléogéographiques en Bulgarie du Nord-Est pendant le Néogene. - C. R. Acad. Bulg. Sci., 34, 9, 1273-1275.

Kojumdgieva, E., N. Popov, M. Stancheva, S. Darakchieva. 1989. Correlation of the biostratigraphic subdivisions of the Neogene in Bulgaria after mollusks, foraminifers and ostracods. - Geologica Balc., 19, 3, 9-22 (in Russan with English abstract).

Koleva-Rekalova, E. 1994. Sarmatian aragonite sediments in Northeastern Bulgaria - origin and diagenesis. - Geologica Balc., 24, 5, 47-64.

Koleva-Rekalova, E. 1997a. Sedimentological characteristic of the Sarmatian rocks from the Balchic area, Northeastern Bulgaria. - Rev. Bulg. Geol. Soc., 58, 1, 31-42 (in Bulgarian with English abstract).

Koleva-Rekalova, E. 1997b. Climate evolution during the Sarmatian of Northeastern Bulgaria (according to sedimentological data). - Geologica Balc., 27, 3-4, 79-82.

Koleva-Rekalova, E. 2019. New findings of the Bessarabian (Sarmatian) limestones composed of Nubecularia novorossica Karrer \& Sinzow, 1887 from the village of Tyulenovo and Cape Shabla, NE Bulgaria. - In: Short Communications of the National Conference "GEOSCIENCES 2019". Rev. Bulg. Geol. Soc., 80, 3, 91-92.

Koleva-Rekalova, E., S. Darakchieva. 2002. The Bessarabian foraminiferal limestones of the Odartsi Formation, Northeastern Bulgaria. - Minno Delo i Geologiya J., 4, 31-33 (in Bulgarian with English abstract).

Koleva-Rekalova, E., S. Darakchieva. 2017. First data on the presence of Nubecularia novorossica Karrer \& Sinzow, 1877 in the Bessarabian limestone of the Odartsi Formation (Northeastern Bulgaria). - In: Short Communications of the National Conference "GEOSCIENCES 2017”. Sofia, Bulg. Geol. Soc., 91-92.

Koubová, I., N. Hudáčková. 2010. Foraminiferal successions in the shallow water Sarmatian sediments from the MZ 93 borehole (Vienna Basin, Slovak part). - Acta Geologica Slovaca, 2, 1, 47-58.

Kováč, M., U. Sliva, B. Sorková, J. Hlavatá, A. Škulová. 2008. Serravallian sequence stratigraphy of the northern Vienna Basin: high frequency cycles in the Sarmatian sedimentary record. - Geologica Carpathica, 59, 6, 545-561.
Loeblich Jr., A. R., H. Tappan. 1988. Foraminiferal Genera and Their Classification. New York, Van Nostrand Reinhold Company, $970 \mathrm{p}$.

Lukeneder, S., M. Zuschin, M. Harzhauser, O. Mandic. 2011. Spatiotemporal signals and palaeoenvironments of endemic molluscan assemblages in the marine system of the Sarmatian Paratethys. - Acta Palaeontol. Polonica, 56, 4, 767-784.

Maisuradze, L. S. 1980. On the Paleobiological History of the Late Miocene Foraminifera of the Euxinic-Caspian Basin. Tbilisi, Metsniereba, 106 p. (in Russian with English abstract).

Miclea, A.-E. 2017. Biostratigraphical and Paleoecological Study of the Sarmatian Foraminiferal Associations in the South-west Area of Borod Basin. Unpublished Summary of PhD Thesis, Cluj-Napoca, Babeş-Bolyai University, 42 p.

Munteanu, E., M.-T. Munteanu. 1997. Correlation of Sarmatian deposits of South Dobrogea and SubCarpatians of Muntenia. - Acta Palaeontol. Romaniae, 1, 155-160.

Palcu, D. V., M. Tulbure, M. Bartol, T. J. Kouwenhoven, W. Krijgsman. 2015. The Badenian-Sarmatian Extinction event in the Carpathian foredeep basin of Romania: Paleogeographic changes in the Paratethys domain. - Glob. Planet. Change, 133, 346-358.

Palcu, D. V., L. A. Golovina, Y. V. Vernyhorova, S. V. Popov, W. Krijgsman. 2017. Middle Miocene paleoenvironmental crises in Central Eurasia caused by changes in marine gateway configuration. - Glob. Planet. Change, 158, 57-71.

Palcu, D. V., I. Vasiliev, M. Stoika, W. Krijgsman. 2019. The end of the Great Khersonian Drying of Eurasia: Magnetostratigraphic dating of the Maeotian transgression in the Eastern Paratethys. - Basin Res., 31, 1, 33-58.

Papp, A. 1956. Fazies und Gliederung des Sarmats im Wiener Becken. - Mitteil. Geol. Ges. Wien, 47, 1-97.

Phleger, F. B. 1960. Ecology and Distribution of Recent Foraminifera. Baltimore, John Hobkins Press, 297 p.

Piller, W. E., M. Harzhauser. 2005. The myth of the brackish Sarmatian Sea. - Terra Nova, 17, 5, 450-455.

Pisera, A. 1996. Miocene reefs of the Paratethys: a review. SEMP Concepts in Sedimentology and Paleontology, 5, 97-104.

Popov, N., E. Kojumdjieva. 1987. The Miocene in Northeastern Bulgaria (lithostratigraphic subdivision and geological evolution). - Rev. Bulg. Geol. Soc., 48, 3, 15-33 (in Bulgarian with English abstract).

Popov, N., M. Stancheva, S. Darakchieva. 1986. Reference sections of the Neogene from Nortwestern Bulgaria. - Palaeont., Stratigr., Lithol., 23, 25-45 (in Bulgarian with English abstract).

Popov, S. V., I. G. Shcherba, L. B. Ilyina, L. A. Nevesskaya, N. P. Paramonova, S. O. Khondrarian, I. Maguar. 2006. Late Miocene to Pliocene palaeogeography of the Paratethys and its relation to the Medirerranean. - Palaegeogr., Palaeoclimatol., Palaeoecol., 238, 1-4, 91-106.

Rögl, F. 1999. Mediterranean and Paratethys. Facts and hypotheses of an Oligocene to Miocene paleogeography (short overview). - Geologica Carpathica, 50, 4, 339-349.

Schneider, S., O. Mandic, M. Harzhauser. 2013. Preserved colour pattern in Polititapes tricuspis (Eichwald, 1829), (Bivalvia: Veneridae) from the Sarmatian holostratotype at Nexing (Lower Austria). - N. Jb. Geol. Paläont. Abh., 268, 2, 191-197.

Simionescu, I. 1903. Contribuţiuni la geologia Moldovei dintre Siret şi Prut. - Acad. Rom., Publ. Fond. V. Adamachi, 9, 7-117.

Suciu, A.-A. 2005. Preliminary data on the Sarmatian deposits from Lombi Hill (Popeşti locality) northwest from ClujNapoca. - Analele Ştiințifice Ale Universității “Al. I. Cuza” IAŞI, Geologie, 51, 121-130. 
Temniskova-Topalova, D. N. 1994. Miocene Diatomic Flora in Bulgaria - Composition, Texture, Evolution, Palaeoecology and Biostratigraphy. Unpublished D.Sci. Thesis. Sofia, Sofia University, Faculty of Biology, 318 p. (in Bulgarian).

Tóth, E., Á. Görög, C. Lécuyer, P. Moissette, V. Balter, M. Monostori. 2010. Palaeoenvironmental reconstruction of the Sarmatian (Middle Miocene) Central Paratethys based on palaeontological and geochemical analyses of foraminifera, ostracods, gastropods and rodents. - Geol. Mag., 147, 2, 299-314.
Vernyhorova, Y. V. 2015. Stratigraphic scheme for the Neogene deposits of the Northern Black Sea Region and adjacent part of the Ukrainian Shield. - Heolohiia ta Rudonosnist Ukrainy, 1, 1, 81-124 (in Ukrainian with English abstract).

Vrsaljko, D., D. Pavelić, M. Miknić, M. Brkić, M. Kovačić, I. Hećimović, V. Hajek-Tadesse, R. Avanić, N. Kurtanjek. 2006. Middle Miocene (Upper Badenian/Sarmatian) palaeoecology and evolution of the environments in the area of Medvednica Mt. (North Croatia). - Geologia Croatica, 59, $1,51-63$.

Постьпила на 07.01.2020 г., приета за печат на 06.03.2020 г. Отговорен редактор Марлена Янева 